\title{
To Study the Histopathological Changes in the Gills of Clarias batrachus, an Air Breathing Teleost after Short Term Exposure of Copper Sulphate
}

Muneesh Kumar ${ }^{1 *}$, Parvinder Kumar ${ }^{2}$ and Sangeeta Devi ${ }^{3}$

${ }^{1}$ Department of Zoology Govt. S.S.L. Jain P.G. College, Vidisha, Barkatullah University Bhopal, India

${ }^{2}$ Department of Zoology and Human Genetics Research Counselling Centre, University of Jammu, Jammu, India

${ }^{3}$ Department of Zoology and Applied Aquaculture Barkatullah University Bhopal, India

\begin{abstract}
Gills are the prime organs for gaseous exchange and perform several other physiological functions including osmoregulation and excretion. Harmful effects of several pesticides on the gill histomorphology are well known. In this paper the effects of heavy metal on the gills of Clarias batrachus is demonstrated. Clarias batrachus, a freshwater teleost were exposed to copper sulphate for $24,48,72$ and $96 \mathrm{~h}$ at $0.25,0.30,0.35$ and $0.40 \mathrm{ppm}$ to determine the LC50 values as well as any histopathological changes to the gills. The histological sections of gills of snake headed air breathing teleost examined under light microscope showed severe structural alterations like mucus cells hyperplasia, bulging of taste buds, formation of interlamellar bridge and sub epithelial spaces in the primary and secondary gill lamellae.
\end{abstract}

Keywords: Gills; Copper Sulphate; Histopathology; Clarias batrachus

\section{Introduction}

Industrial effluent containing heavy metals, on entering aquatic environment causes biochemical disturbances in the fish. Heavy metals and their salts constitute a very important group of environmental pollutants since they are potent metabolic inhibitors. The inherent toxicity of a metal depends upon its capacity to disturb the dynamic life processes in biological system by combining with cell organelles, macromolecules and metabolites. The persistence and ubiquitous nature of these pollutant compounds coupled with their tendency to accumulate in organisms ultimately produce toxic reaction in aquatic biota especially, fish.

Fish live in intimate contact with the surrounding water through their gills [1] whose surface comprises over half of the body surface area. Only a few micron of delicate gill epithelium separate the internal environment of the fish from a continuously flowing external environment [2] Thus, it makes the fish very susceptible to aquatic pollutants. The gradual accumulation of toxic material in water due to run-off from the agricultural land containing insecticides, pesticides, herbicides etc. Dutta et al. [3] have demonstrated the effect of several heavy metals seriously damage the gills of teleostean fish. Hemalatha and Banerjee have studied the toxic impact of the trace element zinc chloride $\left(\mathrm{ZnCl}_{2}\right)$ on the gills and accessory respiratory organs of Heteropneustes fossilis. Parashar et al. [4] have studied the toxicopathological impact of lead nitrate on the gills of air breathing catfish Heteropneustes fossilis. Organophosphates are considered highly toxic to many aquatic species [5,6]. Pandey Govind et al. [7] studied the effect of sodium cyanide on behaviour and respiratory surveillance in Labeo rohita (Ham). Baker [8] has studied the detergent toxicity on the gill of Puntius ticto. In 2012, Rani and Venkataraman reported the effect of malathion on the gills of G. giuris (Ham). Therefore, in the present study efforts have been made to examine the toxicity of copper sulphate on the gills of Clarias batrachus.

\section{Materials and Methods}

Adult and live fish Clarias batrachus were collected from the fish farm Patra and Bhadbhada Bhopal (M.P.) brought to the laboratory, cleaned by using $0.1 \% \mathrm{KMnO}_{4}$ to avoid dermal infection. Only healthy fishes (Length: $12-15 \mathrm{~cm}$, Weight: 50-60 g) were taken for experiment.
Fishes were acclimatized in glass aquaria for 15 days and were fed with earthworms...") and water in the aquaria was replaced by freshwater at every $24 \mathrm{~h}$.

After proper washing with several changes of water the fish were acclimated in clean tap water under normal laboratory condition between $27^{\circ} \mathrm{C}$ to $30^{\circ} \mathrm{C}$ for 15 days. They were fed with commercial fish food (fish tone) and chopped earthworm on alternate days and water was renewed after every $24 \mathrm{~h}$, to eliminate faecal matter and unconsumed food. However, feeding was stopped $24 \mathrm{~h}$ Prior to the commencement of the experiment. Prior to the bio-assay test, $96 \mathrm{~h}$ median lethal concentration (96h LC50) was estimated by standard log-probit method (Sprague, 1976). Five groups of 10 fish each were exposed to $0.4 \mathrm{ppm}$ ( $96 \mathrm{~h} \mathrm{LC}_{50}$ value) of copper sulphate. Each group was exposed separately to $20 \mathrm{~L}$ of copper sulphate solution, prepared in tap water (having dissolved $\mathrm{O}_{2} 7.2 \pm 0.66 \mathrm{~mL} / \mathrm{L}, \mathrm{pH} 7.51 \pm 0.20$, water hardness $34.2 \mathrm{mg} / \mathrm{L}$ and water temperature $25^{\circ} \mathrm{C} \pm 2^{\circ} \mathrm{C}$ ). Five separate battery jars containing $20 \mathrm{~L}$ of fresh tap water having 6 fish in each were used as control.

After the exposure period of $24 \mathrm{~h}, 48 \mathrm{~h}, 72 \mathrm{~h}$ and $96 \mathrm{~h}$, five fish each from the respective experimental, as well as control jars were dissected and the entire gill from both the sides of the fish were taken out and were fixed in $10 \%$ neutral formalin, aqueous bouin's fluid and zenker helly's fluid. $6 \mu \mathrm{m}$ paraffin sections were stained with Harris haemotoxylin and Eosin (H\&E) for routine histopathological analysis.

\section{Results}

The gill is composed of two parts gill head and gill filaments. The gill

*Corresponding author: Muneesh Kumar, Barkatullah University Bhopal India, Tel: +919622149364; E-mail: manishloves200787@gmail.com

Received March 10, 2015; Accepted June 30, 2015; Published July 30, 2015

Citation: Kumar M, Kumar P, Devi S (2015) To Study the Histopathological Changes in the Gills of Clarias batrachus, an Air Breathing Teleost after Short Term Exposure of Copper Sulphate. J Aquac Res Development 6: 369. doi:10.4172/21559546.1000369

Copyright: ( 2015 Kumar M, et al. This is an open-access article distributed under the terms of the Creative Commons Attribution License, which permits unrestricted use, distribution, and reproduction in any medium, provided the original author and source are credited. 
Citation: Kumar M, Kumar P, Devi S (2015) To Study the Histopathological Changes in the Gills of Clarias batrachus, an Air Breathing Teleost after Short Term Exposure of Copper Sulphate. J Aquac Res Development 6: 369. doi:10.4172/2155-9546.1000369

head is covered over by a thick tissue composed of mucus glands, taste buds, and connective tissue. The gill head contains bony part of gill arch and gill rackers. The surface epithelium of gill arch showing parallel arrangement of epithelial cells having mucus pores. Examination of thin sections of gill arch of Clarias batrachus (Control) showing four pairs of typical teleostean gill arches bearing two rows of primary gill filaments. Each gill filament bears a series of alternately arranged semicircular secondary lamellae on both sides (Figure 1). The surface of gill lamella is lined by a thin layer of simple squamous epithelium which rests on basement membrane covering the pillar Cell-blood channel system and which constitutes the main vascular area of the gills (Figure 2). Gills of Clarias batrachus exposed to copper sulphate solution exhibited varying degree of damage in sublethal concentration $(<0.4 \mathrm{ppm})$ after $48 \mathrm{~h}$. Mucus cell hyperplasia was generally more pronounced towards the proximal end of the filament. After $96 \mathrm{~h}$ of exposure, hyperplasia of epithelial cells resulted in the fusion of many lamellae (Figure 3).

In $0.35 \mathrm{ppm}$ exposure up to $96 \mathrm{~h}$ the mucus cells were fed with earthworms..." and become enlarged. Some lamellae appeared thickened and retracted while some were reduced and subepithelial space developed (Figure 4). After $96 \mathrm{~h}$ of exposure, in $<0.4 \mathrm{ppm}$ (sublethal concentration), buldging of taste bud (Figures 5 and 6) gill racker, formation of interlamellar space, fusion of secondary lamellae, breakage of lamellar blood capillaries, swollen tip, telangiectatic secondary lamellae and clotting of blood were observed.

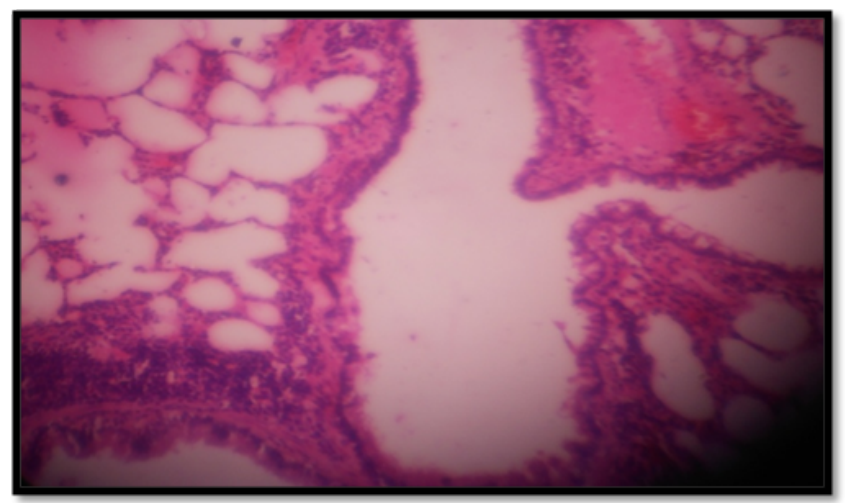

Figure 1: Part of control gill showing structural organization. Note the gill lamella, taste bud and gill arch. H/E 100X.

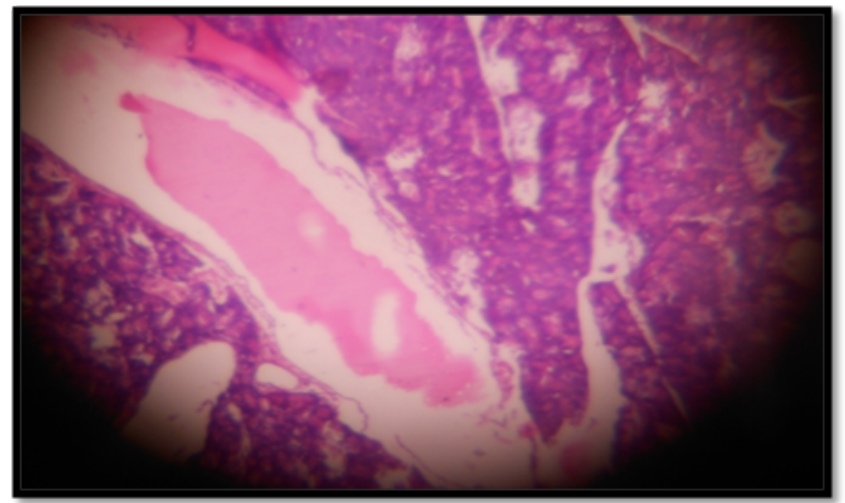

Figure 2: Magnified view of the gill of control fish showing mucous Cell, blood channel and epithelial cell. H/E 400X.

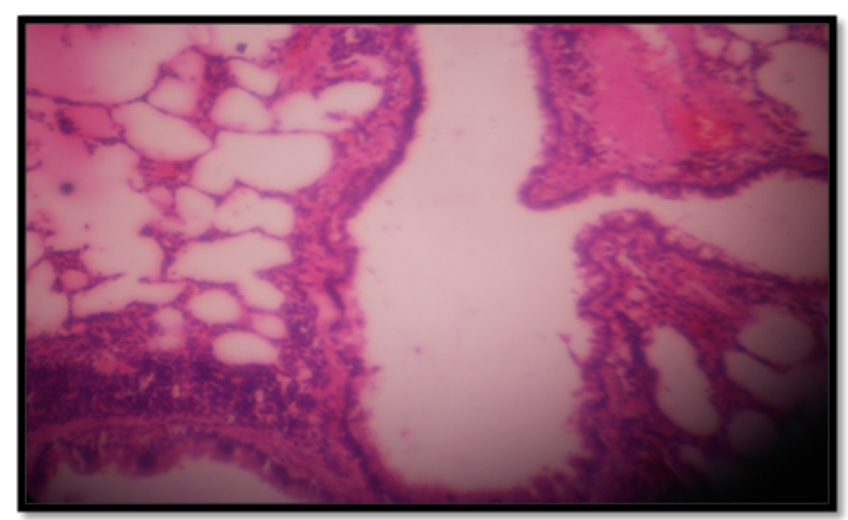

Figure 3: A part of copper sulphate treated gill showing hyperplasia of Epithelial lining the secondary lamella. H/E 150X.

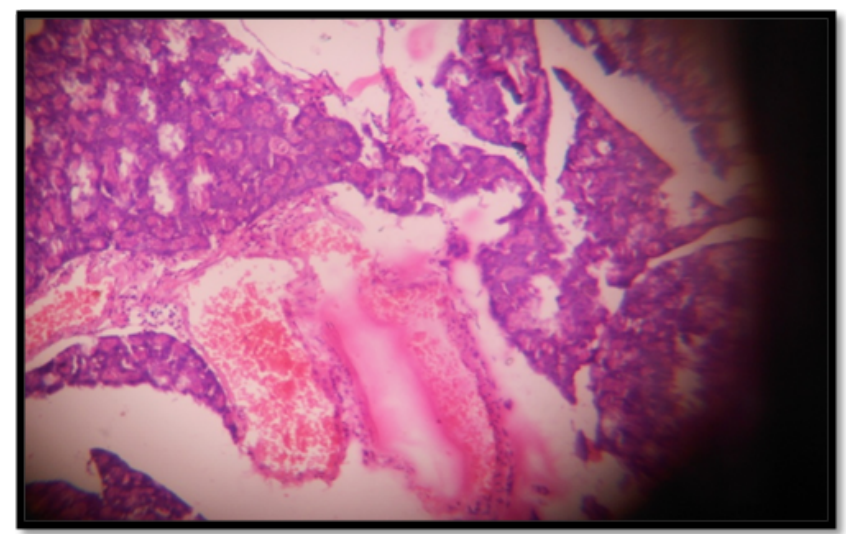

Figure 4: Gill showing sub epithelial space and hyperplasia of Epithelial cells after $96 \mathrm{~h}$ exposure of copper sulphate. H/E 150X.

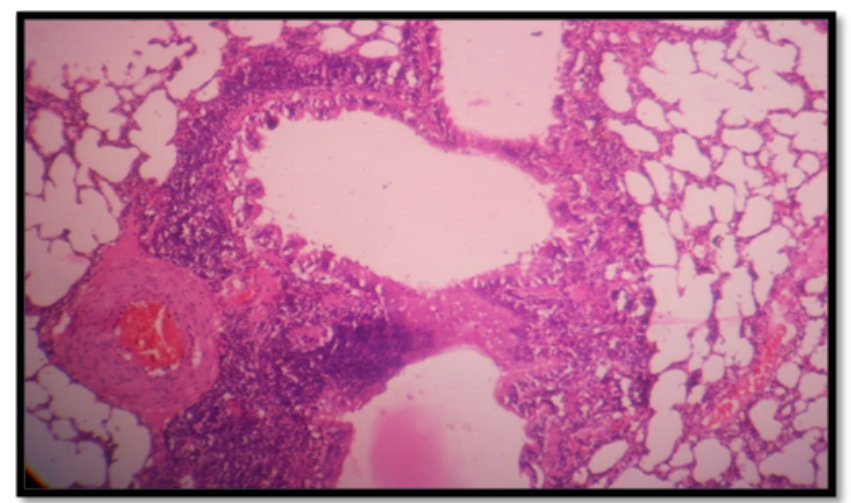

Figure 5: Epithelial cells showing fusion and hyperplasia Along with enlarged mucous cell of secondary lamella. H/E 520X.

\section{Discussion}

Gills have an extensive surface area and minimal diffusion distance between dissolved $\mathrm{O}_{2}$ and blood capillaries for efficient gaseous exchange. However, fish gills are marvellously equipped with a defence mechanism working against the environmental irritants which essentially is the mucus cell. The mucus cells react instantaneously to 


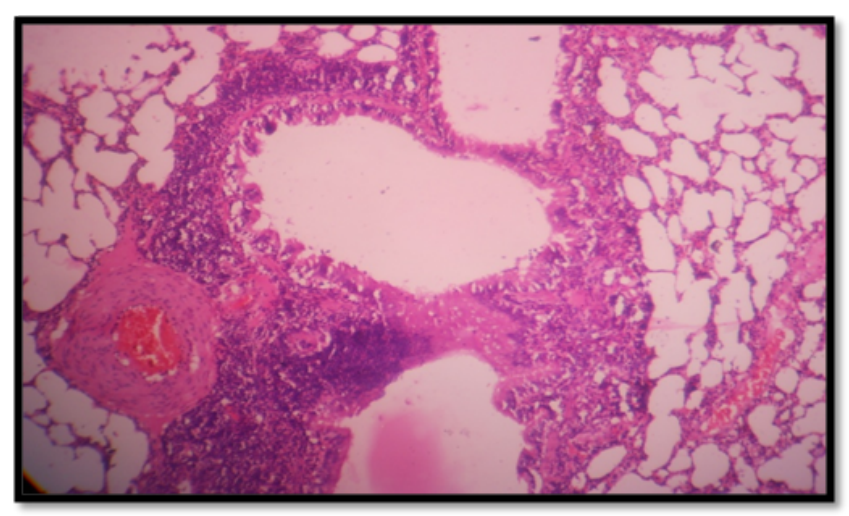

Figure 6: Section of gill arch showing bulged taste bud and Mucous cell after $96 \mathrm{~h}$ of exposure. H/E 300X.

the pollutants and secrete copious mucus to form a thick protective layer over the entire exposed surface, which remain stuck to the mucus. The mucus layer creates a microenvironment that may act as an ion trap, concentrating trace elements in the water. The histomorphological response of the gills of fish exposed to ambient insecticides (including metal salts) is often manifested by a prominent increase in the density of its mucus cells [9-13].

The large amount of mucous secretion acts as a defence mechanism against several toxic substances [14-16]. The regular elimination of mucous layer from the gill surface into aquatic media helps to remove the bound pathogens, toxicants and foreign matters [17] which remain stick to the gills. Playle et al. [18] noticed that the gill microenvironment differs considerably from that of the surrounding body and water causing deposition of metals on the gill surface [19]. Due to copper sulphate intoxication the gill epithelium was completely separated from the basement membrane and pillar cells and there was a swelling of the secondary lamellae and dilation of the vessels. The pillar cell nucleus showed necrosis and vacuolation in the secondary gill epithelium. The disorganised fusion in secondary gill epithelium was prominently observed after exposure of the toxicants. Histopathological change in the gill of Labeo rohita was reported by Velmurugan et al. [20] after exposure of the fish to organophosphate pesticide monocrotophos. According to their investigation epithelial proliferation, congestion of blood vessel and hyperplasia of mucus cells was reported in the gills.

The similar changes were also observed by Kumaraguru et al., and Rani et al. [21,22]. The structural alterations in the gill morphology had been categorised by Dutta et al. [3] into two groups: (1) the insecticides causing necrosis and rupture of the branchial epithelium. These changes are dose dependent and often reported under lethal conditions. The death of branchial cells and their rupture usually develops either by autolysis or by rapid lysis caused by the direct action of toxicants on the cells' constituents [23] and (2) branchial defence response achieved by mucus hypersecretion, epithelial lifting, swelling, hyperplasia and lamellar fusion.

It is well established that secondary gill lamellae play an important role in the transport of respiratory gases. The damage done to the lamellae might have reduced the $\mathrm{O}_{2}$ transport which in turn would have influence the metabolic system of the fish. The accumulation of the pesticide on gill imitated the elevation of mucus secretion and decreased ventilation which ultimately decreased the $\mathrm{O}_{2}$ uptake through gills. The similar observation was reported by Prashanth et al.,
Bradbury et al. [6,24,25]. Wannee et al. [26] was observed the epithelial lifting and aneurysn in the Nile tilapia, Oreochromis niloticus under exposure to glyphosate for $96 \mathrm{~h}$. The enlargement of chloride secreting cells and their nuclei supports the above assumption.

The periodic secretion of mucus might be one of the important means for elimination of toxicants from the surface of gills. This finding also matches with the observation of Pandey Govind et al. [7]. Witters et al. [27] observed that complexion with organic material lowers the harmful effect of toxicants on the gill surface. Arillo et al. [28] stated that some components of mucus probably the protein bound sulphydryl groups, have a deep toxifying function against ambient toxins. One of the prominent phenomenons that have been observed in present investigation was the fusion of secondary lamella. This was due to counter stress and may also be due to transformation of electrically charged properties of the epithelial cells which favour adhesion between the cells of two neighbouring secondary lamellae. The fusion of secondary lamellae causing a drastic reduction in the respiratory surface area. Several other toxicants are also known to induce fusion of secondary lamella of gills $[3,4,29,20]$. Hence it is reasonable to conclude that copper sulphate intoxication caused severe aerobic stress in Clarias batrachus. Collapsing of slimy protective covering that fails to prevent the penetration of insecticide. This leads to various degrees of wear and tear, which causes damage to thin protective device of the gill epithelium of Clarias batrachus.

The other changes in the gill epithelium that occurred after the exposure to copper sulphate includes the separation of respiratory epithelium from basement membrane that increases the thickness of secondary lamella as similar to the findings of Parashar et al., and Karlsson Norrgren et al. [4,31]. The increasing thickness of SL decrease the diffusion capacity, it might be to form an additional barrier to prevent the entering of insecticides dissolved in water. Identical lifting of the respiratory epithelium of the SL of the gills and/or ARO has also been observed in $H$. fossilis subjected to desiccation stress [4] and Lead nitrate exposure [32].

\section{Conclusion}

After the above discussion it had been concluded copper causes deleterious effects on fishes. In sub lethal concentration it may be fatal for an individual organism and it also affect the growth rate and reproduction resulting in disturbance to whole community and also tropic levels of food chains, ultimately the ecosystem.

\section{Acknowledgement}

Authors are beholden to Principal Dr. A.K. Gangely S.L.L. Jain P.G. College Vidisha, Bhopal M.P. India for providing laboratory facilities for this research work. This paper forms the part of Ph.D. thesis submitted by author to Barkatullah University, Bhopal M.P. (India)

\section{References}

1. Pratap HB, Fu H, Lock RAC, Bonga SE (1989) Effect of water borne and dietary cadmium on plasma ions of the teleost Oreochromis mossambicus in relation to water calcium levels. Arch Environ Contam Toxicol 18: 568-575.

2. Wood CM, Soivio A (1991) Environmental effects on gill function-An introduction. Physiological zoology 64: 1-3.

3. Dutta HM, Munshi JSD, Roy PK, Singh NK, Adhikari S (1996) Ultrastructura changes in the respiratory lamellae of the catfish Heteropneustes fossilis after sublethal exposure of malathion. Environ Pollut 3: 329-341.

4. Parashar RS, Banerjee TK (2002) Toxic impact of lethal concentration of lead nitrate on the gills of air breathing catfish Heteropneustes fossilis (Bloch). Vet Arhiv 72: 167-183.

5. Qin JG, Dong P (2004) Acute toxicity of trichlorfon to juvenile yabby Cherax 
Citation: Kumar M, Kumar P, Devi S (2015) To Study the Histopathological Changes in the Gills of Clarias batrachus, an Air Breathing Teleost after Short Term Exposure of Copper Sulphate. J Aquac Res Development 6: 369. doi:10.4172/2155-9546.1000369

destructor (Clark) and selected zooplankton species. Aquacult Res 35: 11041107.

6. Prashanth MS, Sayeswara HA, Goudar MA (2011) Effect of sodium cyanide on behaviour and respiratory surveillance in freshwater fish Labeo rohita (Ham). Recent Research in Science and Technology 3: 24-30

7. Pandey Govind, Varsha J, Mishra KD, Madhuri S (2011) Linear alkyl benzene sulphonate a detergent induced toxicity on the gill of Puntius ticto fish. IRJP 2: $76-78$

8. Baker JTP (1969) Histological and electron microscopical observations on copper poisoning in the winter flounder (Pseudopleuronectes americanus). J Fish Res Board Can 26: 2785 -2793.

9. Cardeilhac PT, Simpson CP, Loverlock RL, Yosha SE, Calderwood HW, et al. (1979) Failure of osmoregulation with apparent potassium intoxication in marine teleosts primary toxic effect of copper. Aquaculture 17: 231-239.

10. Matey VE (1984) Comparative analysis of the gill epithelium ultrastructure in the perch Perca fluviatillis from basins with different composition. Tsitologiya 778-782.

11. Wise ML, Stiebel CL, Grizzp JM (1987) Acute toxicity to nitrofurazone to channel catfish Ictalurus punctatus and goldfish Carassius auratus. Bull Environ Contam Toxicol: 42-46.

12. Dutta HM (1997) A composite approach for evaluation of the effect of pesticides on fish. In: Munshi JSD, Dutta HM (eds.) Fish morphology Horizon of new research. Science Publisher Inc., USA, pp. 249-277.

13. Mc Donald DG (1983) The effect of $\mathrm{H}+$ upon the gills of freshwater fish. Can $J$ Zool 65: 691-703.

14. Handy RD, Eddy FB (1991) The absence of mucous on the secondary lamellae of unstressed rainbow trout Oncorhynchus mykiss. J Fish Biol 38: 153-155.

15. Mazon AF, Cerqueira CCC, Monteriro EAS, Fernandes MN (1999) Acute copper exposure in freshwater fish Morphological and physiological effects. In: Val AL, Almieidaval VMF (eds.) Biology of Tropical Fishes. INPA Manaus, pp. 263-275

16. Powell MD, Speare DJ, Burka JF (1992) Fixation of mucus on rainbow trout (Onchorhynchus mykiss Walbaum) gills for light and electron microscopy. J Fish Biol 41: 813-824.

17. Peuranen S, Vuorinen PJ, Vuorinen M, Hollender A (1994) The effect of iron humic acids and low $\mathrm{pH}$ on the gills and physiology of brown trout (Salmo trutta). Ann Zool Fennici 31: 389-396.

18. Playle R, Wood CM (1989) Water chemistry changes in the gill microenvironment of rainbow trout experimental observations and theory. J comp Physiol B 159 : 527-537.
19. Vijaya Lakshmi S, Tilak KS (1996) Effect of pesticides on the gill morphology of Labeo rohita. J Ecotoxicol Environ Monit 6: 059-064.

20. Velmurugan G, Selvanayagam M, Cergiz EI , Unlu E (2009) Histopathological changes in the gill and liver tissues of freshwater fish Cirrhinus mrigala exposed to dichlorvos. Braz Arcr Biol Technol 52: 1291-1296.

21. Kumaraguru AK, Beamish FWH, Ferguson HW (1982) Direct and circulatory paths of permethrin causing histopathological changes in the gills of rainbow trout. J Fish Biol 29: 87-90.

22. Rani S, Venkataramana GV (2010) Effects of the organophosphorous malathion on the branchial gills of a freshwater fish Glossogobius giuris (Ham) I JSN 3: 324-330.

23. Abel PD (1976) Toxic action of several lethal concentrations of an ionic detergent on the gills of the brown trout (SL). J Fish Biol 9: 442-446.

24. Bradbury SP, James MM, Joel Loats R (1987) Physiological response of rainbow trout (Salmo gairdeneri) to acute fenvalerate intoxication. J Pest Biochem Phy 27: 275-288.

25. Bradbury SP, Coats JR (1989) Comparative toxicology of the pyrethroid insecticide. Revi Environ Contam Toxicol 108: 133-177.

26. Wannee Jiraung Koorskul, Suchart Uptham E, Maleeya K, Somphong S, et al. (2002) Histopathological effects of roundup a glyphosate herbicide on Nile tilapia Oreochromis niloticus. Science Asia 28: 121-127

27. Witters HE, Van Puymbroeck S, Vangenechten JHD, Vanderbrorght OLJ (1990) The effect of humic substances on the toxicity of aluminium to adult rainbow trout Onchorhynchus mykiss (walbaum). J Fish Bio 37: 43-53.

28. Arillo A, Melodia F (1990) Protective effect of fish mucus against $\mathrm{Cr}$ (VI) pollution. Chemosphere 20: 397-402.

29. Leino RL,Wilkinson P, Anderson DG (1987) Histopathological changes in the gills of pearl dace Semotilus margarita and fathead minnows Pimephales promleas from experimentally acidified lakes. Ca J Fish Aqua Sci 44: 216-234.

30. Wendelaar Bonga SE (1997) The stress response in Fish. Fish Physiol Rev 77: 591-625.

31. Karlsson Norrgren L, Runn P, Haux C, Forlin L (1985) Cadmium induced changes in gill morphology of zebra fish Brachydanio rerio (Hamilton-Buchanan) and rainbow trout Salmo gairdneri (Richardson). J Fish Biol 27: 81-95.

32. Parashar RS, Banerjee TK (1999) A Histopathological analysis of subletha toxicity induced by lead nitrate to the accessory respiratory organs of the airbreathing teleost Heteropneustes fossilis (Bloch). Pol Arch Hydrobiol 46 194-205. 